\title{
The Repositioning of Citizenship and Alienage: Emergent Subjects and Spaces for Politics*
}

\author{
SASKIA SASSEN \\ University of Chicago
}

ABSTRACT The two foundational subjects for membership in the modern nation-state, the citizen and the alien, are undergoing significant changes in the current period. The effect is a partial blurring of each the citizen subject and the alien subject. Some of these changes are not formalized and hence become particularly evident in certain types of contexts, foremost among which are cities. These can be seen as productive spaces for informal or notyet-formalized politics and subjects. In this examination of emergent possibilities, I first outline these changes vis-à-vis nationality and citizenship. Second, I dissect notions of national membership in order to create a set of tools for reconstructing citizenship analytically. In the third section, I delineate two key, incipient kinds of repositioned membership: unauthorized yet recognized subjects, and authorized yet unrecognized subjects. Fourth, I situate these repositionings within contemporary currents of citizenship theory. In the final section, I theorize the landscape of the global city as an especially salient site for the repositioning of citizenship in practice. At the scale of the city, and the particular urban space of the global city, there are dynamics that signal the possibilities for a politics of membership that is simultaneously localized and transnational.

Most of the scholarship on citizenship has claimed a necessary connection to the national state. The transformations afoot today raise questions about this proposition insofar as they significantly alter those conditions which in the past fed that articulation between citizenship and the national state. The context for this possible alteration is defined by two major, partly interconnected conditions. One is the change in the position and institutional features of national states since the 1980s resulting from various types of globalization-linked policies. These range from economic privatization and deregulation to the increased prominence of the 
international human rights regime. The second is the emergence of multiple actors, groups, and communities partly strengthened by these transformations in the state and increasingly unwilling automatically to identify with a nation as represented by the state.

Addressing the question of citizenship against these transformations entails a specific stance. It is quite possible to posit that at the most abstract or formal level not much has changed over the last century in the essential features of citizenship. The theoretical ground from which I address the issue is that of the historicity and the embeddedness of both categories, citizenship and the national state, rather than their purely formal features. Each of these has been constructed in elaborate and formal ways. And each has evolved historically as a tightly packaged bundle of what were in fact often rather diverse elements. The dynamics at work today are destabilizing these particular bundlings and bringing to the fore the fact itself of that bundling and its particularity. Through their destabilizing effects, these dynamics are producing operational and rhetorical openings for the emergence of new types of political subjects and new spatialities for politics.

More broadly, the destabilizing of national state-centered hierarchies of legitimate power and allegiance has enabled a multiplication of non-formalized or only partly formalized political dynamics and actors. These signal a deterritorializing of citizenship practices and identities, and of discourses about loyalty and allegiance. Finally, specific transformations inside the national state have directly and indirectly altered particular features of the institution of citizenship. These transformations are not predicated necessarily on deterritorialization or locations for the institution outside the national state as is key to conceptions of postnational citizenship, and hence are usefully distinguished from current notions of postnational citizenship. I will refer to these as denationalized forms of citizenship.

Analytically, I seek to understand how various transformations entail continuities or discontinuities in the basic institutional form. That is to say, where do we see continuities in the formal bundle of rights at the heart of the institution and where do we see movement towards postnational and/or denationalized features of citizenship? And where might as yet informal citizenship practices engender formalizations of new types of rights? Particular attention goes to several specific issues that capture these features. One of these is the relationship between citizenship and nationality and the evolution of the latter towards something akin to 'effective' nationality rather than as 'allegiance' to one state or exclusively formal nationality. A later section examines the mix of distinct elements that actually make up the category of citizenship in today's highly developed countries. Far from being a unitary category or a mere legal status, these diverse elements can be contradictory. One of my assumptions here is that the destabilizing impact of globalization contributes to accentuate the distinctiveness of each of these elements. A case in point is the growing tension between the legal form and the normative project towards enhanced inclusion as various minorities and disadvantaged sectors gain visibility for their claim-making. Critical here is the failure in most countries to achieve 'equal' citizenshipthat is, not just a formal status but an enabling condition.

The remaining sections begin to theorize these issues with a view towards specifying incipient and typically not formalized developments in the institution of citizenship. Informal practices and political subjects not quite fully recognized as such can nonetheless function as part of the political landscape. Undocumented immigrants who are long-term residents engage in practices that are the same as those of formally defined citizens in the routines of daily life; this produces an informal social contract between these undocumented immigrants and the community. Subjects who are by definition categorized as non-political, such as 'housewives', may actually have considerable political agency and be emergent political subjects. Insofar as 
citizenship is at least partly shaped by the conditions within which it is embedded, conditions that have today changed in certain very specific and also general ways, we may well be seeing a corresponding set of changes in the institution itself. These may not yet be formalized and some may never become fully formalized. Further, social constructions that mark individuals, such as race and ethnicity, may well become destabilized by these developments in both the institution of citizenship and the nation-state. Generally, the analysis in this paper suggests that we might see an unbounding of existing types of subjects, particularly dominant ones such as the citizen-subject, the alien, and the racialized subject.

A concluding section argues that many of these transformations in the broader context and in the institution itself become legible in today's large cities. Perhaps the most evolved type of site for these transformations is the global city. ${ }^{1}$ In this process, the global city is reconfigured as a partly denationalized space that enables a partial reinvention of citizenship. This reinvention takes the institution away from questions of nationality narrowly defined and towards the enactment of a large array of particular interests, from protests against police brutality and globalization to sexual preference politics and house-squatting by anarchists. I interpret this as a move towards citizenship practices that revolve around claiming rights to the city. These are not exclusively or necessarily urban practices. But it is especially in large cities that we see simultaneously some of the most extreme inequalities as well as conditions enabling these citizenship practices. In global cities, these practices also contain the possibility of directly engaging strategic forms of power, a fact which I interpret as significant in a context where power is increasingly privatized, globalized, and elusive.

\section{Citizenship and Nationality}

In its narrowest definition citizenship describes the legal relationship between the individual and the polity. This relation can in principle assume many forms, in good part depending on the definition of the polity. Thus, in Europe this definition of the polity was originally the city, both in ancient and in medieval times. But it is the evolution of polities along the lines of state formation that gave citizenship in the west its full institutionalized and formalized character and that made nationality a key component of citizenship.

Today the terms citizenship and nationality both refer to the national state. In a technical legal sense, while essentially the same concept, each term reflects a different legal framework. Both identify the legal status of an individual in terms of state membership. But citizenship is largely confined to the national dimension, while nationality refers to the international legal dimension in the context of an interstate system. The legal status entails the specifics of whom the state recognizes as a citizen and the formal basis for the rights and responsibilities of the individual in relation to the state. International law affirms that each state may determine who will be considered a citizen of that state (see Hague Convention 1954). Domestic laws about who is a citizen vary significantly across states and so do the definitions of what it entails to be a citizen. Even within Europe, let alone worldwide, there are marked differences in how citizenship is articulated and hence how non-citizens are defined.

The aggressive nationalism and territorial competition among European states in the eighteenth, nineteenth and well into the twentieth centuries made the concept of dual nationality generally undesirable, incompatible with individual loyalties, and destabilizing of the international order. Absolute state authority over a territory and its nationals could not easily accommodate dual nationality. Indeed, we see the development of a series of mechanisms aimed at preventing or counteracting the common causes for dual nationality (Marrus, 1985). This 
negative perception of dual nationality continued into the first half of the twentieth century and well into the 1960s. There were no international accords on dual nationality. The main effort by the international system remained rooting out the causes of dual nationality by means of multilateral codification of the law on the subject (Rubenstein \& Adler, 2000). It is probably the case that this particular form of the institution of citizenship, centered on exclusive allegiance, reached its highpoint in the twentieth century.

The major transformations of the 1980s and into the 21st century have once again brought conditions for a change in the institution of citizenship and its relation to nationality, and they have brought about changes in the legal content of nationality. Mostly minor formal and informal changes are beginning to dilute the particular formalization coming out of European history. The long lasting resistance to dual or multiple nationality is shifting towards a selective acceptance. According to some legal scholars (Spiro, 1997; Rubenstein \& Adler, 2000), in the future dual and multiple nationality will become the norm. Today, we see growing numbers of people with dual nationality (Spiro, 1997). Insofar as the importance of nationality is a function of the central role of states in the international system, it is quite possible that a decline in the importance of this role and a proliferation of other actors will affect the value of nationality.

These transformations may give citizenship yet another set of features as it continues to respond to the conditions within which it is embedded (Sassen, 1996: Chap. 2). The nationalizing of the institution, which took place over the last several centuries, may today give way to a partial denationalizing. A fundamental dynamic in this regard is the growing articulation of national economies with the global economy and the associated pressures on states to be competitive. Crucial to current notions of competitive states is withdrawal from various spheres of citizenship entitlements, with the possibility of a corresponding dilution of loyalty to the state. Citizens' loyalty may in turn be less crucial to the state today than at a time of people-intensive and frequent warfare, with its need for loyal citizen-soldiers (Turner, 2000). Masses of troops today can be replaced by technologically intensive methods of warfare. Most importantly, in the highly developed world, warfare has become less significant partly due to economic globalization. Global firms and global markets do not want the rich countries to fight wars among themselves. The resistance to join the Bush Administration's call to war on Iraq illuminates this. The 'international' project of the most powerful actors on the world stage today is radically different from what it was in the nineteenth and first half of the twentieth centuries.

Many of the dynamics that built economies, polities, and societies in the nineteenth and twentieth centuries contained an articulation between the national scale and the growth of entitlements for citizens. During industrialization, class formation, class struggles, and the advantages of both employers and workers tended to scale at the national level and became identified with state-produced legislation and regulations, entitlements and obligations. The state came to be seen as a key to ensuring the well-being of significant portions of both the working class and the bourgeoisie. The development of welfare states in the twentieth century became a crucial institutional domain for granting entitlements to the poor and the disadvantaged. Today, the growing weight given to notions of the 'competitiveness' of states puts pressure on states to cut down on these entitlements. This in turn weakens the reciprocal relationship between the poor and the state (e.g. Munger, 2002). Finally, the growth of unemployment and the fact that many of the young are developing weak ties to the labor market, once thought of as a crucial mechanism for the socialization of young adults, will further weaken the loyalty and sense of reciprocity between these future adults and the state (Roulleau-Berger, 2002). 
As these trends have come together towards the end of the twentieth century they are contributing to destabilize the meaning of citizenship as it was forged in the nineteenth and much of the twentieth century. Economic policies and technical developments we associate with economic globalization have strengthened the importance of cross-border dynamics and reduced that of borders. The associated emphasis on markets has brought into question the foundations of the welfare state. T. H. Marshall (1977 [1950]) and many others saw and continue to see the welfare state as an important ingredient of social citizenship. Today the assumptions of the dominant model of Marshallian citizenship have been severely diluted under the impact of globalization and the ascendance of the market as the preferred mechanism for addressing these social issues. For many critics, the reliance on markets to solve political and social problems is a savage attack on the principles of citizenship. Thus Peter Saunders (1993) argues that citizenship inscribed in the institutions of the welfare state is a buffer against the vagaries of the market and the inequalities of the class system.

The nature of citizenship has also been challenged by a proliferation of old issues that have gained new attention. Among the latter are the question of state membership of aboriginal communities, stateless people, and refugees (Sassen, 1999; Knop, 2002). All of these have important implications for human rights in relation to citizenship. These social changes in the role of the state, the impact of globalization on states, and the relationship between dominant and subordinate groups also have major implications for questions of identity. 'Is citizenship a useful concept for exploring the problems of belonging, identity and personality in the modern world?' (Shotter, 1993; Ong, 1999, Chaps. 1 \& 4). Can such a radical change in the conditions for citizenship leave the institution itself unchanged?

\section{Deconstructing Citizenship}

Though often talked about as a single concept and experienced as a unitary institution, citizenship actually describes a number of discrete but related aspects in the relation between the individual and the polity. Current developments are bringing to light and accentuating the distinctiveness of these various aspects, from formal rights to practices and psychological dimensions (see Ong, 1996; Bosniak, 2000). They make legible the tension between citizenship as a formal legal status and as a normative project or an aspiration. The formal equality granted to all citizens rarely rests on the need for substantive equality in social and even political terms. In brief, current conditions have strengthened the emphasis on rights and aspirations that go beyond the formal legal definition of rights and obligations.

This is mirrored most recently in the reinvigoration of theoretical distinctions: communitarian and deliberative, republican and liberal, feminist, postnational and cosmopolitan notions of citizenship. Insofar as citizenship is a status which articulates legal rights and responsibilities, the mechanisms through which this articulation is shaped and implemented can be analytically distinguished from the status itself and so can the content of the rights. In the medieval cities so admired by Max Weber (1958), it was urban residents themselves who set up the structures through which to establish and thicken their rights in the space of the city. Today it is the national state that provides these mechanisms and it does so for national political space. But these mechanisms may well be changing once again given globalization, the associated changes in the national state, and the ascendance of human rights. In each of these major phases, the actual content and shape of the legal rights and obligations also changed.

Some of these issues can be illustrated through the evolution of equal citizenship over the last few decades. Equal citizenship is central to the modern institution of citizenship. The expansion 
of equality among citizens has shaped a good part of its evolution in the twentieth century. There is debate as to what brought about the expanded inclusions over this period, most notably the granting of the vote to women. For some (e.g. Karst, 2000) it is law itself-and national law - that has been crucial in promoting recognition of exclusions and measures for their elimination. For others (Young, 1990; Taylor, 1992) politics and identity have been essential because they provide the sense of solidarity necessary for the further development of modern citizenship in the nation-state. Either way, insofar as equality is based on membership, citizenship status forms the basis of an exclusive politics and identity (Walzer, 1985; Bosniak, 1996).

In a country such as the US, the principle of equal citizenship remains unfulfilled, even after the successful struggles and legal advances of the last five decades (Karst, 1997). ${ }^{2}$ Groups defined by race, ethnicity, religion, sex, sexual orientation, and other 'identities', still face various exclusions from full participation in public life notwithstanding formal equality as citizens. Second, because full participation as a citizen rests on a material base (Marshall, 1977; Handler, 1995) poverty excludes large sectors of the population and the gap is widening. Feminist and race-critical scholarship have highlighted the failure of gender- and race-neutral conceptions of citizenship, such as legal status, to account for the differences of individuals within communities (Benhabib et al., 1995; Crenshaw et al., 1996; Delgado \& Stefancic, 2001; Benhabib, 2002). In brief, legal citizenship does not always bring full and equal membership rights. Citizenship is affected by the position of different groups within a nation-state.

Yet it is precisely the position of these different groups that has engendered the practices and struggles that forced changes in the institution of citizenship itself. Thus Kenneth Karst (1997) observes that in the US it was national law that 'braided the strands of citizenship' - formal legal status, rights, belonging-into the principle of equal citizenship. This took place through a series of Supreme Court decisions and acts of Congress beginning with the Civil Rights Act of 1964. Karst emphasizes how important these constitutional and legislative instruments are, and that we cannot take citizenship for granted or be complacent about it.

There are two aspects here that matter for my argument. This history of interactions between differential positionings and expanded inclusions signals the possibility that the new conditions of inequality and difference evident today and the new types of claim-making they produce may well bring about further transformations in the institution. Citizenship is partly produced by the practices of the excluded. Secondly, by expanding the formal inclusionary aspect of citizenship, the national state contributed to create some of the conditions that eventually would facilitate key aspects of postnational citizenship. At the same time, insofar as the state itself has undergone significant transformation, notably the changes bundled under the notion of the competitive state, it may reduce the chances that state institutions will do the type of legislative and judiciary work that has led to expanded formal inclusions.

The consequence of these two developments may well be the absence of a lineal progression in the evolution of the institution. The expanding inclusions that we have seen in the US since the 1960s may have produced conditions which make possible forms of citizenship that follow a different trajectory. Furthermore, the pressures of globalization on national states may mean that claim-making will increasingly be directed at other institutions as well. This is already evident in a variety of instances. One example is the decision by first-nation people to go directly to the UN and claim direct representation in international fora, rather than going through the national state. It is also evident in the increasingly institutionalized framework of the international human rights regime and the emergent possibilities for bypassing unilateral state sovereignty. 
As the importance of equality in citizenship has grown and become more visible, and as the role of national law in giving presence and voice to hitherto silenced minorities has grown, the tension between the formal status and the normative project of citizenship has also grown. For many, citizenship is becoming a normative project whereby social membership becomes increasingly comprehensive and open ended. Globalization and human rights are further enabling this tension and therewith furthering the elements of a new discourse on rights. These developments signal that the analytic terrain within which we need to place the question of rights, authority and obligations is shifting (Sassen, 1996, Chap. 2; Sassen, 2006). Some of these issues can be illustrated by two contrasting cases described below.

\section{Towards Effective Nationality and Informal Citizenship}

\section{Unauthorized yet Recognized}

Perhaps one of the more extreme instances of a condition akin to effective as opposed to formal nationality is what has been called the informal social contract that binds undocumented immigrants to their communities of residence (Schuck \& Smith, 1985). Thus, unauthorized immigrants who demonstrate civic involvement, social deservedness, and national loyalty can argue that they merit legal residency. To make this brief examination more specific, I will focus on one case, undocumented immigrants in the US.

Individuals, even when undocumented immigrants, can move between the multiple meanings of citizenship. The daily practices by undocumented immigrants as part of their daily life in the community where they reside_-such as raising a family, schooling children, holding a job-earn them citizenship claims in the US even as the formal status and, more narrowly, legalization may continue to evade them. There are dimensions of citizenship, such as strong community ties and participation in civic activities, which are being enacted informally through these practices. These practices produce an at least partial recognition of them as full social beings. In many countries around the world, including the US, long term undocumented residents often can gain legal residence if they can document the fact of this long term residence and 'good conduct'. US immigration law recognizes such informal participation as grounds for granting legal residency. For instance, prior to the new immigration law passed in 1996, individuals who could prove seven years of continuous presence, good moral character, and that deportation would be an extreme hardship, were eligible for suspension of deportation, and thus US residency. NACARA extended the eligibility of this suspension of deportation to some 300,000 Salvadorans and Guatemalans who were unauthorized residents in the US. ${ }^{3}$

The case of undocumented immigrants is, in many ways, a very particular and special illustration of a condition akin to 'effective' citizenship and nationality. One way of interpreting this dynamic in the light of the discussion in the preceding sections is to emphasize that it is the fact of the multiple dimensions of citizenship which engenders strategies for legitimizing informal or extra-statal forms of membership (Soysal, 1994; Coutin, 2000). The practices of these undocumented immigrants are a form of citizenship practices and their identities as members of a community of residence assume some of the features of citizenship identities. Supposedly this could hold even in the communitarian model where the community can decide on whom to admit and whom to exclude, but once admitted, proper civic practices earn full membership.

Further, the practices of migrants, even if undocumented, can contribute to recognition of their rights in countries of origin. During the 1981-92 civil war, Salvadoran migrants even though citizens of El Salvador were directly and indirectly excluded from El Salvador 
through political violence, enormous economic hardship, and direct persecution (Mahler, 1995). They could not enjoy their rights as citizens. After fleeing, many continued to provide support to their families and communities. Further, migrants' remittances became a key factor for El Salvador's economy - as they are for several countries around the world. The government of El Salvador actually began to support the emigrants' fight to get residency rights in the US, even joining US-based activist organizations in this effort. The Salvadoran government was thus supporting Salvadorans who were the formerly excluded enemy citizens-they needed those remittances to keep coming and they wanted the emigrants to stay out of the Salvadoran workforce given high unemployment. Thus the participation of these undocumented migrants in cross-border community, family, and political networks has contributed to increasing recognition of their legal and political rights as Salvadoran citizens (Coutin, 2000; Mahler, 1996).

According to Coutin (2000) and others, movements between membership and exclusion, and between different dimensions of citizenship, legitimacy and illegitimacy, may be as important as redefinitions of citizenship itself. Given scarce resources, the possibility of negotiating the different dimensions of citizenship may well represent an important enabling condition. Undocumented immigrants develop informal, covert, often extra-statal strategies and networks connecting them with communities in sending countries. Hometowns rely on their remittances and their information about jobs in the US. Sending remittances illegally by an unauthorized immigrant can be seen as an act of patriotism, and working as an undocumented immigrant can be seen as contributing to the host economy. Multiple interdependencies are thereby established and grounds for claims on the receiving and the originating country can conceivably also be established even when the immigrants are undocumented and laws are broken (Basch et al., 1994; Cordero-Guzmán et al., 2001).

\section{Authorized yet Unrecognized}

At perhaps the other extreme of undocumented immigrants whose practices allow them to become accepted as members of the political community is the case of those who are full citizens yet not recognized as political subjects through discrimination, cultural stereotyping, etc.

In an enormously insightful study of Japanese housewives, Robin LeBlanc (1999) finds precisely this combination. Being a housewife is basically a full-time occupation in Japan and restricts Japanese women's public life in many important ways, both practical and symbolical. A 'housewife' in Japan is a person whose very identity is customarily that of a particularistic, non-political actor. Yet, paradoxically, it is also a condition providing these women with a unique vehicle for other forms of public participation, where being a housewife is an advantage denied to those who might have the qualifications for higher level political life. LeBlanc documents how the housewife has an advantage in the world of local politics or the political life of a local area: she can be trusted precisely because she is a housewife; she can build networks with other housewives; hers is the image of desirable public concern and of a powerful-because believable-critic of mainstream politics.

There is something extremely important in this condition which is shared with women in other cultures and vis-à-vis different issues. For instance, and in a very different register, women emerged as a specific type of political actor during the brutal dictatorships of the 1970s and 1980 s in several countries of Latin America. It was precisely their condition as mothers and wives that gave them the clarity and the courage to demand justice and to demand bread and to do so confronting armed soldiers and policemen. Mothers in the barrios of Santiago during Pinochet's dictatorship, the Mothers of the Plaza de Mayo in Buenos Aires, the 
mothers regularly demonstrating in front of the major prisons in El Salvador during the civil war-all were driven to political action by their despair at the loss of children and husbands and the struggle to provide food in their homes. And they were recognized as such.

Further, and in a very different type of situation, there is an interesting parallel between LeBlanc's capturing of the political in the condition of the housewife and a set of findings in some of the research on immigrant women in the US. There is growing evidence that immigrant women are more likely than immigrant men to emerge as actors in the public domain precisely because of their responsibilities in the household. Regular wage work and improved access to other public realms has an impact on their culturally specified subordinate role to men in the household. Immigrant women gain greater personal autonomy and independence while immigrant men lose ground compared to what was their condition in cultures of origin. Women gain more control over budgeting and other domestic decisions, and greater leverage in requesting help from men in domestic chores. Their responsibility for securing public services and other public resources for their families gives them a chance to become incorporated in the mainstream society-they are often the ones in the household who mediate in this process (e.g., Chinchilla \& Hamilton, 2001). It is likely that some women benefit more than others from these circumstances; we need more research to establish the impact of class, education, and income on these gendered outcomes.

Besides the relatively greater empowerment of immigrant women in the household associated with waged employment, what matters here is their greater participation in the public sphere and their possible emergence as public actors. There are two arenas where immigrant women are active: institutions for public and private assistance, and the immigrant or ethnic community. The incorporation of women in the migration process strengthens the settlement likelihood and contributes to greater immigrant participation in their communities and vis-à-vis the state. For instance, Pierrette Hondagneu-Sotelo (1994) found immigrant women come to assume more active public and social roles, which further reinforces their status in the household and the settlement process. These immigrant women are more active in community building and community activism and they are positioned differently from men regarding the broader economy and the state. They are the ones that are likely to have to handle the legal vulnerability of their families in the process of seeking public and social services for their families. This greater participation by women suggests the possibility that they may emerge as more forceful and visible actors and make their role in the labor market more visible as well. ${ }^{4}$

These are dimensions of citizenship and citizenship practices that do not fit the indicators and categories of mainstream frameworks for understanding citizenship and political life. Women in the condition of housewives and mothers do not fit the categories and indicators used to capture participation in political life. Feminist scholarship in all the social sciences has had to deal with a set of similar or equivalent difficulties and tensions in its effort to constitute its subject or to reconfigure a subject that has been flattened. The theoretical and empirical distance that has to be bridged between the recognized world of politics and the as yet unmapped experience of citizenship of the housewife - not of women as such, but of women as housewives-is a distance we encounter in many types of inquiry. Bridging this distance requires specific forms of empirical research and of theorization.

\section{Postnational or Denationalized?}

From the perspective of nation-based citizenship theory, some of these transformations might be interpreted as a decline or devaluation of citizenship or, more favorably, as a displacement of 
citizenship in the face of other forms of collective organization and affiliation, as yet unnamed (Bosniak, 2000). Insofar as citizenship is theorized as necessarily national (e.g. Himmelfarb, 2001), by definition these new developments cannot be captured in the language of citizenship. ${ }^{5}$ An alternative interpretation would be to suspend the national, as in postnational conceptions, and to posit that the issue of where citizenship is enacted is an empirical question (e.g. Soysal, 1994; Jacobson, 1996; Torres, 1998; Torres et al., 1999; Isin \& Turner, 2002).

From where I look at these issues, there is a third possibility, beyond these two. It is that citizenship-even if situated in institutional settings that are 'national'-is a possibly changed institution if the meaning of the national itself has changed (Sasson, 2006, ch. 6). That is to say, insofar as globalization has changed certain features of the territorial and institutional organization of the political power and authority of the state, the institution of citizenship — its formal rights, its practices, its psychological dimension-has also been transformed even when it remains centered in the national state. I have argued, for instance, that this territorial and institutional transformation of state power and authority has produced operational, conceptual and rhetorical openings for nation-based subjects other than the national state to emerge as legitimate actors in international and global arenas that used to be exclusive to the state (see Indiana Journal of Global Legal Studies, 1996).

I distinguish what I would narrowly define as denationalized from postnational citizenship, the latter the term most commonly used and the only one used in the broader debate. ${ }^{6}$ In my reading we are dealing with two distinct dynamics rather than only the emergence of locations for citizenship outside the frame of the national state. Their difference is a question of scope and institutional embeddedness. The understanding in the scholarship is that postnational citizenship is located partly outside the confines of the national. In considering denationalization, the focus moves on to the transformation of the national, including the national in its condition as foundational for citizenship. Thus it could be argued that postnationalism and denationalization represent two different trajectories. Both are viable, and they do not exclude each other.

The national, then, remains a referent in my work (e.g., Sassen, 2006). But, clearly, it is a referent of a specific sort: it is, after all, its change that becomes the key theoretical feature through which it enters my specification of changes in the institution of citizenship. Whether or not this devalues citizenship (Jacobson, 1996) is not immediately evident to me at this point. Citizenship has undergone many transformations in its history precisely because it is to variable extents embedded in the specifics of each of its eras. ${ }^{7}$ Significant to my argument here is also the fact discussed earlier about the importance of national law in the process of expanding inclusions, inclusions which today are destabilizing older notions of citizenship. This pluralized meaning of citizenship, partly produced by the formal expansions of the legal status of citizenship and through the institutionalization of the human rights regime, is today contributing to explode the boundaries of that legal status even further.

First, and most importantly in my reading, is the strengthening, including the constitutionalizing, of civil rights which allow citizens to make claims against their states and allow them to invoke a measure of autonomy in the formal political arena that can be read as a lengthening distance between the formal apparatus of the state and the institution of citizenship. The implications, both political and theoretical, of this dimension are complex and in the making: we cannot tell what will be the practices and rhetorics that might be invented.

Secondly, I add to this the granting, by national states, of a whole range of 'rights' to foreign actors, largely and especially, economic actors-foreign firms, foreign investors, international markets, foreign business people (see Sassen, 1996: Chap. 2). Admittedly, this is not a common way of framing the issue. It comes out of my particular perspective about the 
impact of globalization and denationalization on the national state, including the impact on the relation between the state and its own citizens, and the state and foreign economic actors. I see this as a significant, though not much recognized, development in the history of claim-making. For me the question as to how citizens should handle these new concentrations of power and 'legitimacy' that attach to global firms and markets is a key to the future of democracy. My efforts to detect the extent to which the global is embedded and filtered through the national (e.g., the concept of the global city-Sassen, 2001; Bartlett, in process) is one way of understanding whether therein lies a possibility for citizens, still largely confined to national institutions, to demand accountability of global economic actors through national institutional channels, rather than having to wait for a 'global' state.

\section{Citizenship in the Global City}

The particular transformations in the understanding and theorization of citizenship discussed thus far bring us back to some of the earlier historical formations around questions of citizenship, most prominently the crucial role played by cities and civil society. The large city of today, most especially the global city, emerges as a strategic site for these new types of operations. It is one of the nexuses where the formation of new claims materializes and assumes concrete forms. The loss of power at the national level produces the possibility for new forms of power and politics at the subnational level. The national as container of social process and power is cracked. This cracked casing opens up possibilities for a geography of politics that links subnational spaces. Cities are foremost in this new geography. One question this engenders is how and whether we are seeing the formation of new types of politics that localize in these cities.

If we consider that large cities concentrate both the leading sectors of global capital and a growing share of disadvantaged populations-immigrants, many of the disadvantaged women, people of color generally, and, in the megacities of developing countries, masses of shanty dwellers - then we can see that cities have become a strategic terrain for a whole series of conflicts and contradictions. We can then think of cities also as one of the sites for the contradictions of the globalization of capital, even though, heeding Ira Katznelson's (1992) observation, the city cannot be reduced to this dynamic. Recovering cities along these lines means recovering the multiplicity of presences in this landscape. The large city of today has emerged as a strategic site for a whole range of new types of operations-political, economic, cultural, subjective (Drainville, 2004; Isin, 2000; Allen et al., 1999; Bridge \& Watson, 2000).

While citizenship originated in cities and cities played an important role in its evolution, I do not think we can simply read some of these current developments as a return to that older historical condition. The significance of the city today as a setting for engendering new types of citizenship practices and new types of incompletely formalized political subjects does not derive from that history. Nor does current local city government have much to do with earlier notions of citizenship and democracy described for ancient and medieval cities in Europe (Isin, 2000, p. 7). It is, rather, more connected to what Henri Lefebvre $(1991$; 1995) was capturing when describing the city as oeuvre and hence the importance of agency. Where Lefebvre found this agency in the working class in the modern (Fordist) city, I find it in two strategic actors-global corporate capital and immigration-in today's global cities. Here I would like to return to the fact of the embeddedness of the institution of citizenship.

What is being engendered today in terms of citizenship practices in the global city is quite different from what it might have been in the medieval city of Weber. In the medieval city 
we see a set of practices that allowed the burghers to set up systems for owning and protecting property and to implement various immunities against despots of all sorts. ${ }^{8}$ Today's citizenship practices have to do with the production of 'presence' of those without power and a politics that claims rights to the city. What the two situations share is the notion that through these practices new forms of citizenship are being constituted and that the city is a key site for this type of political work and is, indeed, partly constituted through these dynamics. After the long historical phase that saw the ascendance of the national state and the scaling of key economic dynamics at the national level, the city is once again today a scale for strategic economic and political dynamics.

In his effort to specify the ideal-typical features of what constitutes the city, Weber sought out a certain type of city-most prominently the cities of the late Middle Ages rather than the modern industrial cities of his time. Weber sought a kind of city that combined conditions and dynamics which forced its residents and leaders into creative, innovative responses and adaptations. Further, he posited that these changes produced in the context of the city signaled transformations that went beyond the city, and that could have a far reach in instituting often fundamental transformations. In that regard the city offered the possibility of understanding far-reaching changes that could - under certain conditions-eventually encompass society at large.

There are two aspects of Weber's The City (1958) that are of particular importance here. Weber sought to understand under what conditions cities can be positive and creative influences on people's lives. For Weber, cities are a set of social structures that encourage social individuality and innovation and hence are an instrument of historical change. There is in this intellectual project a deep sense of the historicity of these conditions. For Weber, modern urban life did not correspond to this positive and creative power of cities; Weber saw modern cities as dominated by large factories and office bureaucracies. My own reading of the Fordist city corresponds in many ways to Weber's in the sense that the strategic scale under Fordism is the national scale and cities lose significance. It is the large Fordist factory and the mines which emerge as key sites for the political work of the disadvantaged and those without power.

For Weber, it is particularly the cities of the late Middle Ages that combine the conditions that pushed urban residents, merchants, artisans and leaders to address them and deal with them. These transformations could make for epochal change beyond the city itself: Weber shows us how in many of these cities these struggles led to the creation of the elements of what we could call governance systems and citizenship. In this regard, struggles around political, economic, legal, cultural, issues which are centered in the realities of cities can become the catalysts for new transurban developments in all these institutional domains: markets, participatory governance, rights for members of the urban community regardless of lineage, judicial recourse, cultures of engagement and deliberation.

The particular analytic element I want to extricate from this aspect of Weber's understanding and theorization of the city is the historicity of those conditions that make cities strategic sites for the enactment of important transformations in multiple institutional domains. Elsewhere (Sassen, 2001) I have developed the argument that today a certain type of city-the global city-has emerged as a strategic site precisely for such innovations and transformations in multiple institutional domains. Several of the key components of economic globalization and digitization instantiate in this type of city and produce dislocations and destabilizations of existing institutional orders and legal, regulatory, and normative frames for handling urban conditions. It is the high level of concentration of these new dynamics in these cities that forces creative responses and innovations. There is, most probably, a threshold effect at work here. 
The historicity of this process rests in the fact that under Keynesian policies, particularly the Fordist contract, and the dominance of mass manufacturing as the organizing economic dynamic, cities had lost strategic functions and were not the site for creative institutional innovations. The strategic sites were the large factory and the whole process of mass manufacturing and mass consumer markets, and, secondly, the national government where regulatory frameworks were developed and the Fordist contract instituted. The factory and the government were the strategic sites where the crucial dynamics producing the major institutional innovations of the epoch were located.

With globalization and digitization—and all the specific elements they entail—global cities emerge as such strategic sites. While the strategic transformations are sharply concentrated in global cities, many of the transformations are also enacted, besides being diffused, in cities at lower orders of national urban hierarchies. Furthermore, in my reading, particular institutions of the state also are such strategic sites even as there is an overall shrinking of state authority through deregulation and privatization (e.g., Body-Gendrot, 1999; Wacquant, 2004).

A second analytic element I want to extricate from Weber's The City is the particular type of embeddedness of the transformations he describes and renders as ideal-typical features. This is not an embeddedness in what we might think of as deep structures because the latter are precisely the ones that are being dislocated or changed and are creating openings for new fundamental arrangements to emerge. The embeddedness is, rather, in very specific conditions, opportunities, constraints, needs, interactions, contestations, interests. The aspect that matters here is the complexity, detail, and social thickness of the particular conditions and the dynamics he identifies as enabling change and innovation. This complexity and thickness also produces ambiguities in the meaning of the changes and innovations. It is not always clear whether they are positive-where we might interpret positive as meaning the creation or strengthening of some element, even if very partial or minor, of participatory democracy in the city-and in what timeframe their positiveness would become evident. In those cities of the late Middle Ages he saw as being what the city is about, he finds contradictory and multivalent innovations. He dissects these innovations to understand what they can produce or launch.

The argument I derive from this particular type of embeddedness of change and innovation is that current conditions in global cities are creating not only new structurations of power but also operational and rhetorical openings for new types of political actors which may have been submerged, invisible, or without voice. A key element of the argument here is that the localization of strategic components of globalization in these cities means that the disadvantaged can engage the new forms of globalized corporate power, and secondly that the growing numbers and diversity of the disadvantaged in these cities under these conditions assumes a distinctive 'presence'. This entails a distinction between powerlessness and invisibility or impotence. The disadvantaged in global cities can gain 'presence' in their engagement with power but also vis-à-vis each other. This is different from the 1950s-1970s period in the US, for instance, when white flight and the significant departure of major corporate headquarters left cities hollowed out and the disadvantaged in a condition of abandonment. Today, the localization of the global creates a set of objective conditions of engagement. This can be seen, for example, in the struggles against gentrification-which encroaches on minority and disadvantaged neighborhoods and led to growing numbers of homeless beginning in the 1980s - and the struggles for the rights of the homeless, or also in demonstrations against police brutalizing minority people. These struggles are different from the ghetto uprisings of the 1960s, which were short, intense eruptions confined to the ghettos and causing most of the damage in the neighborhoods of the disadvantaged themselves. In these ghetto uprisings there was no engagement with power. 
The conditions that today mark the possibility of cities as strategic sites are basically two, and both capture major transformations that are destabilizing older systems organizing territory and politics. One of these is the re-scaling of what are the strategic territories that articulate the new political-economic system. The other is the partial unbundling or at least weakening of the national as container of social process due to the variety of dynamics encompassed by globalization and digitization. The consequences for cities of these two conditions are many: what matters here is that cities emerge as strategic sites for major economic processes and for new types of political actors. Insofar as citizenship is embedded and in turn marked by its embeddedness, these new conditions may well signal the possibility of new forms of citizenship practices and identities.

There is something to be captured here-a distinction between powerlessness and the condition of being an actor even though lacking power. I use the term presence to name this condition. In the context of a strategic space such as the global city, the types of disadvantaged people described here are not simply marginal; they acquire presence in a broader political process that escapes the boundaries of the formal polity. This presence signals the possibility of a politics. What this politics will be will depend on the specific projects and practices of various communities. Insofar as the sense of membership of these communities is not subsumed under the national, it may well signal the possibility of a politics that, while transnational, is actually centered in concrete localities.

\section{Notes}

This text is based on a keynote lecture from 7 March 2002 conference of the Berkeley Journal of Sociology, 'Race and Ethnicity in a Global Context' at the University of California, Berkeley. It was published in 2002 in the Berkeley Journal of Sociology, Volume 46, pp. 4-26 under the title 'The Repositioning of Citizenship: Emergent Subjects and Spaces for Politics'.

1 For the full treatment of my concept of the global city, see the updated second edition of The Global City: New York, London, Tokyo (Sassen, 2001).

2 In Kenneth Karst's interpretation of US law, aliens are 'constitutionally entitled to most of the guarantees of equal citizenship, and the Supreme Court has accepted this idea to a modest degree' (Karst, 2000, p. 599; see also fn. 20 where he cites cases). Karst also notes that the Supreme Court has not carried this development nearly as far as he might wish.

3 NACARA is the 1997 Nicaraguan Adjustment and Central American Relief Act. It created an amnesty for 300,000 Salvadorans and Guatemalans to apply for suspension of deportation. This is an immigration remedy that had been eliminated by the Illegal Immigration Reform and Immigrant Responsibility Act in 1996 (see Coutin, 2000).

4 For the limits of this process see, e.g., Parreñas, 2001.

5 Thus for Karst 'In the US today, citizenship is inextricable from a complex legal framework that includes a widely accepted body of substantive law, strong law-making institutions, and law-enforcing institutions capable of performing their task' (2000, p. 600). Not recognizing the centrality of the law is, for Karst, a big mistake. Postnational citizenship lacks an institutional framework that can protect the substantive values of citizenship. Karst does acknowledge the possibility of rabid nationalism and the exclusion of aliens when legal status is made central.

6 Bosniak (2000) uses denationalized interchangeably with postnational. I do not.

7 In this regard, I have emphasized as significant (1996, Chap. 2) the introduction in the new constitutions of South Africa, Brazil, Argentina, and the Central European countries, of a provision that qualifies what had been an unqualified right — if democratically elected — of the sovereign to be the exclusive representative of its people in international fora.

8 Only in Russia — where the walled city did not evolve as a center of urban immunities and liberties—does the meaning of citizen diverge from concepts of civil society and cities, and belong to the state, not the city (Weber, 1958). 


\section{References}

Allen, J., Massey, D. \& Pryke, M., Eds (1999) Unsettling Cities (London: Routledge).

Basch, L., Glick Schiller, N. \& Blanc-Szanton, C. (1994) Nations Unbound: Transnational Projects, Postcolonial Predicaments, and Deterritorialized Nation-States (Langhorne, PA: Gordon \& Breach).

Bartlett, A. (forthcoming) Political Subjectivity in the Global City (Ph.D. Dissertation, Department of Sociology, University of Chicago).

Benhabib, S. (2002) Democractic Equality and Cultural Diversity: Political Identities in the Global Era (Princeton, NJ: Princeton University Press).

Benhabib, S., Butler, J., Cornell, D. \& Fraser, N. (1995) Feminist Contentions: A Philosophical Exchange (New York: Routledge).

Body-Gendrot, S. (1999) The Social Control of Cities (London: Blackwell).

Bosniak, L. (1996) 'Nativism' the concept: some reflections, in: J. Perea (Ed) Immigrants Out! The New Nativism and the Anti-Immigrant Impulse in the United States (New York: NYU Press).

Bosnaik, L. (2000) Citizenship denationalized, Indiana Journal of Global Legal Studies, 7(2), pp. 447-509.

Bridge, G. \& Watson, S., Eds (2000) A Companion to the City (Oxford, UK: Blackwell).

Chinchilla, N. \& Hamilton, N. (2001) Seeking Community in the Global City: Salvadorans and Guatemalans in Los Angeles (Philadelphia, PA: Temple University Press).

Cordero-Guzmán, H. R., Smith, R. C. \& Grosfoguel, R., Eds (2001) Migration, Transnationalization, and Race in a Changing New York (Philadelphia, PA: Temple University Press).

Coutin, S. B. (2000) Denationalization, inclusion, and exclusion: negotiating the boundaries of belonging, Indiana Journal of Global Legal Studies, 7(2), pp. 585-594.

Crenshaw, K., Gotanda, N., Peller, G. \& Thomas, K., Eds (1996) Critical Race Theory: The Key Writings that Formed the Movement (New York: New Press).

Delgado, R. \& Stefancic, J., Eds (2001) Critical Race Theory: The Cutting Edge (Philadelphia, PA: Temple University Press).

Drainville, A. (2004) Contesting Globalization: Space and Place in the World Economy (London: Routledge).

Hague Convention (1954) Available at http://exchanges.state.gov/education/culprop/hague.html

Handler, J. (1995) The Poverty of Welfare Reform (New Haven, CT: Yale University Press).

Himmelfarb, G. (2001) One Nation, Two Cultures: A Searching Examination of American Society in the Aftermath of Our Cultural Revolution (New York: Vintage Books).

Hondagneu-Sotelo, P. (1994) Gendered Transitions: Mexican Experiences of Immigration (Berkeley, CA: University of California Press).

Indiana Journal of Global Legal Studies (1996) Special Issue: Feminism and globalization: the impact of the global economy on women and feminist theory, 4(1).

Isin, E. (2000) Introduction: democracy, citizenship and the city, pp. 1-22 in E. Isin (Ed) Democracy, Citizenship and the Global City (New York: Routledge).

Isin, E. \& Turner, B. S., Eds (2002) Handbook of Citizenship Studies (London, Thousand Oaks, CA: Sage).

Jacobson, D. (1996) Rights Across Borders: Immigration and the Decline of Citizenship (Baltimore, MD: Johns Hopkins Press).

Karst, K. (1997) The coming crisis of work in constitutional perspective, Cornell Law Review, 82(3), pp. $523-571$.

Karst, K. (2000) Citizenship, law, and the American nation, Indiana Journal of Global Legal Studies, 7(2), pp. 595-601.

Katznelson, I. (1992) Marxism and the City (Oxford: Clarendon).

Knop, K. (2002) Diversity and Self-Determination in International Law (Cambridge, UK: Cambridge University Press).

LeBlanc, R. (1999) Bicycle Citizens: The Political World of the Japanese Housewife (Berkeley, CA: University of California Press).

Lefebvre, H. (1991) The Production of Space (Cambridge, MA: Blackwell).

Lefebvre, H. (1995) Writing on Cities (Cambridge, MA: Blackwell).

Mahler, S. (1995) American Dreaming: Immigrant Life on the Margins (Princeton, NJ: Princeton University Press).

Marrus, M. R. (1985) The Unwanted: European Refugees in the Twentieth Century (New York: Oxford University Press).

Marshall, T. H. \& Lipset, S. M. (1977[1950]) Class, Citizenship, and Social Development (Chicago, IL: University of Chicago Press).

Munger, F., Ed (2002) Laboring Under the Line (New York: Russell Sage Foundation).

Ong, A. (1996) Strategic sisterhood or sisters in solidarity? Questions of communitarianism and citizenship in Asia, Indiana Journal of Global Legal Studies, 4(1), pp. 107-135.

Ong, A. (1999) Flexible Citizenship: The Cultural Logics of Transnationality (Durham, NC: Duke University Press). 


\section{S. Sassen}

Portes, A. (1996). Global villagers: the rise of transnational communities, American Prospect, 7(25), pp. 74-77.

Parreñas, R. S. (2001) Servants of Globalization: Women, Migration and Domestic Work (Stanford, CA: Stanford University Press).

Roulleau-Berger, L., Ed (2002) Youth and Work in the Postindustrial Cities of North America and Europe (Leiden, Netherlands: Brill).

Rubenstein, K. \& Adler, D. (2000) International citizenship: the future of nationality in a globalized world, Indiana Journal of Global Legal Studies, 7(2), pp. 519-548.

Sassen, S. (1996) Losing Control? Sovereignty in an Age of Globalization (New York: Columbia University Press).

Sassen, S. (1999) Guests and Aliens (New York: New Press).

Sassen, S. (2001) The Global City: New York, London, Tokyo, 2nd edition (Princeton, NJ: Princeton University Press).

Sassen, S. (2006) Denationalization: Territory, Authority, and Rights in a Global Digital Age (Princeton, NJ: Princeton University Press).

Saunders, P. (1993) Citizenship in a liberal society, pp. 57-90 in B. Turner (Ed) Citizenship and Social Theory (London: Sage).

Schuck, P. \& Smith, R. (1985) Citizenship without Consent: Illegal Aliens in the American Polity (New Haven, CT: Yale University Press).

Shotter, J. (1993) Psychology and citizenship: identity and belonging, pp. 115-138 in B. Turner (Ed) Citizenship and Social Theory (London: Sage).

Soysal, Y. N. (1994) Limits of Citizenship: Migrants and Postnational Membership in Europe (Chicago, IL: University of Chicago Press).

Spiro, P. (1997) Dual nationality and the meaning of citizenship, Emory Law Review, 46(4), pp. 1412-1485.

Taylor, C. (1992) The politics of recognition, pp. 25-74 in C. Taylor \& A. Gutmann (Eds) Multiculturalism: Examining the Politics of Recognition (Princeton, NJ: Princeton University Press).

Torres, M. de los Angeles. (1998) Transnational political and cultural identities: crossing theoretical borders, pp. 169182 in F. Bonilla, E. Mélendez, R. Morales \& M. de los Á. Torres (Eds) Borderless Borders (Philadelphia, PA: Temple University Press).

Torres, R. D., Inda, J. X. \& Miron, L. F. (1999) Race, Identity, and Citizenship (Oxford: Blackwell).

Turner, B. (2000) Cosmopolitan virtue: loyalty and the city, pp. 129-147 in E. Isin (Ed) Democracy, Citizenship and the Global City (New York, NY: Routledge).

Wacquant, L. (2004) Ghetto, pp. 129-147 in N. J. Smelser and P. B. Baltes (Eds) International Encyclopedia of the Social and Behavioral Sciences (London: Pergamon Press, rev. ed).

Walzer, M. (1985) Spheres of Justice: A Defense of Pluralism and Equality (New York: Basic Books).

Weber, M. (1958) The City (New York: Free Press).

Young, I. M. (1990) Justice and the Politics of Difference (Princeton, NJ: Princeton University Press). 
Copyright of Globalizations is the property of Routledge, Ltd.. The copyright in an individual article may be maintained by the author in certain cases. Content may not be copied or emailed to multiple sites or posted to a listserv without the copyright holder's express written permission. However, users may print, download, or email articles for individual use. 
Copyright of Globalizations is the property of Routledge, Ltd.. The copyright in an individual article may be maintained by the author in certain cases. Content may not be copied or emailed to multiple sites or posted to a listserv without the copyright holder's express written permission. However, users may print, download, or email articles for individual use. 